\title{
Evaluation of Recycled Tiles and OSB Ceiling Materials in Closed Broiler House Prototypes
}

Duthor(s)
Cravo JCM ${ }^{1}$
Fiorelli $\mathrm{J}^{2}$
Lahr FAR ${ }^{3}$
Fonseca R da
Cruz VC da ${ }^{5}$
1 Undergraduate student in Animal Science,
Universidade Estadual Paulista Júlio de
Mesquita Filho - Dracena campus.
2 Professor, Ph.D, Universidade de São Paulo
- Faculdade de Zootecnia e Engenharia de
Alimento - Pirassununga campus.
3 Head Professor, Universidade de São Paulo
- Escola de Engenharia de São Carlos.
4.5 Professor, Ph.D., Universidade Estadual
Paulista Júlio de Mesquita Filho - Dracena
campus.

\section{Mail Address}

Julio Cesar Machado Cravo

Rua Rubens de Souza Araujo, n663

Vila Mangalot

05132-000. São Paulo, SP, Brasil.

Tel. (11) 30903-2124 ou (11) 8524-6834

E-mail: juliomachadomachado@hotmail.com juliomachadomachado@yahoo.com.br

\section{Keywords}

Broiler house environment, recycled tiles, thermal comfort.

\section{ABSTRACT}

This study aimed at evaluating the thermal performance of a modular ceiling system for poultry houses. The reduced- and distorted-scale prototypes used ceiling modules made of reforested wood and were covered with recycled long-life package tiles. The following parameters were measured for 21 days: tile internal surface temperature (ST), globe temperature and humidity index (WBGT), and radiant heat load (RHL). Measurements were made at times of highest heat load (11:00 am, 13:00 pm, and 03:00 pm). Collected data were analyzed by "R " statistics software. Means were compared by multiple comparison test (Tukey) and linear regression was performed, both at $5 \%$ significance level. The results showed that the prototype with the ceiling was more efficient to reduce internal tile surface temperature; however, this was not sufficient to provide a comfortable environment for broilers during the growout. Therefore, other techniques to provide proper cooling are required in addition to the ceiling

\section{INTRODUCTION}

Poultry production is one of fastest developing agricultural activities in Brazil in the last few decades. This progress, as demonstrated by the number of marketed broilers and eggs, shows the excellent potential of the local poultry industry to supply a healthy and low-cost protein source to consumers (Macari, 2001). The importance of this industry is also demonstrated by chicken meat export figures, which, according to ABEF (Brazilian Association of Chicken Exporters), was 3.3 million tonnes in 2007, representing a 21\% increase relative to 2006 (ABEF, 2008).

Despite the significant growth of the Brazilian poultry industry, broiler production still faces many challenges with the increasing productivity rates. In tropical countries, such as Brazil, the most challenging environmental factors are high temperature and high humidity inside the poultry houses, which may result in heat stress, limiting poultry productivity (Macari, 2001). Therefore, in order to improve intensive poultry production in those countries, companies and experts in poultryhouse environment need to plan the houses with maximum thermal isolation in order to reduce the direct negative effects on climate on birds.

In animal housing, one of the main factors that affect incident radiation thermal load is the roof, especially due to their material (Silva \& Sevegnani, 2001). The only layer that separates birds from the external environment is the roof, as in open-sided poultry houses, the side curtains do not provide efficient insulation. This demonstrates the importance of choosing the adequate roof material (Tinôco, 2001).

Fiorelli et al. (2009) studied the influence of recycled tiles made of recycled long-life packaging material on the thermal comfort of broiler 


\section{Cravo JCM, Fiorelli J, Lahr FAR, Fonseca R da, Cruz VC da}

Evaluation of Recycled Tiles and OSB Ceiling Materials in Closed Broiler House Prototypes houses as compared to traditional roofing material (clay tiles, fiber-cement, or white-painted clay tiles). Environmental indexes (WBGT, RHL e THI) were evaluated in two different heights - at $0.7 \mathrm{~m}$ and $1.5 \mathrm{~m}$ from the floor, and during different times of the day, the materials presented similar behaviors, showing that recycled tiles may be a roofing material alternative for animal housing.

Conceição et al. (2008) evaluated different roofing materials (white-washed asbestos tiles, clay tiles, and tiles made of high-oven scrap and vegetable fibers) in prototypes in reduced and distorted scale. According to those authors, the best environmental indexes results were obtained in the prototype covered with whitewashed asbestos tiles. As to the two other roofing materials (clay and vegetable fiber tiles), similar thermal performance was obtained, therefore demonstrating that a tiles made of vegetable fiber may be a good alternative as roofing material for rural buildings.

Several different materials are used in association in rural buildings when the shadow provided by roofs are not capable of providing an adequate micro-climate inside broiler houses. Among these materials, Costa (1982) points out the use of a ceiling, which may reduce environmental temperature in up to $62 \%$ when a house with no ceiling is compared to a non-ventilated duratex ceiling.

Therefore, this study aimed at studying the thermal performance of a modular roofing system for broiler houses using reforesting wood material, OSB panel, and tiles made of long-life recycled packages in closed prototypes in a reduced and distorted scale.

\section{MATERIALS AND METHODS}

The study was carried out at the Experimental Campus of UNESP Dracena, located at $21029^{\prime} \mathrm{S}$ latitude, 510 52' W longitude, and $421 \mathrm{~m}$ latitude. Annual rainfall is $1235.9 \mathrm{~mm}$, and the climate of the region is of type $C_{w^{\prime}}$ with dry winters, according to the classification of Koppen.

A completely randomized experimental design in a $3 \times 3$ factorial arrangement for thermal comfort indexes (WBGT e RHL) e $2 \times 3$ for superficial temperature (ST) were applied. Factors corresponded to different thermal conditions (HWC - house with ceiling; HWOC - house without ceiling; and $\mathrm{O}$ - outside) and different collection times (11:00 am, 01:00 pm, and 03:00 pm). Thermal comfort indexes were evaluated as a function of three thermal conditions and three temperature times), with a total of nine treatments. Superficial temperature was evaluated as a function of two thermal conditions and three collection times, totaling six treatments.

The models were built in a reduced and distorted scale (1:2 vertically and 1:10 horizontally). One model was built with recycled tiles and OSB as roofing material, previously evaluated by Fiorelli et al. (2009), and was called House with Ceiling (HWC), whereas the other model used only recycled tiles and no ceiling, being called House without Ceiling. Models were $2.0 \mathrm{~m}$ long, $1.4 \mathrm{~m}$ wide, $1.5 \mathrm{~m}$ high, and $0.4 \mathrm{~m}$ high from the floor to the roof. The houses were built longitudinally from eastwest, as this region is usually hot and dry (Figure 01). All sides (north, south, east, and west) of both prototypes were closed with blue plastic curtain.
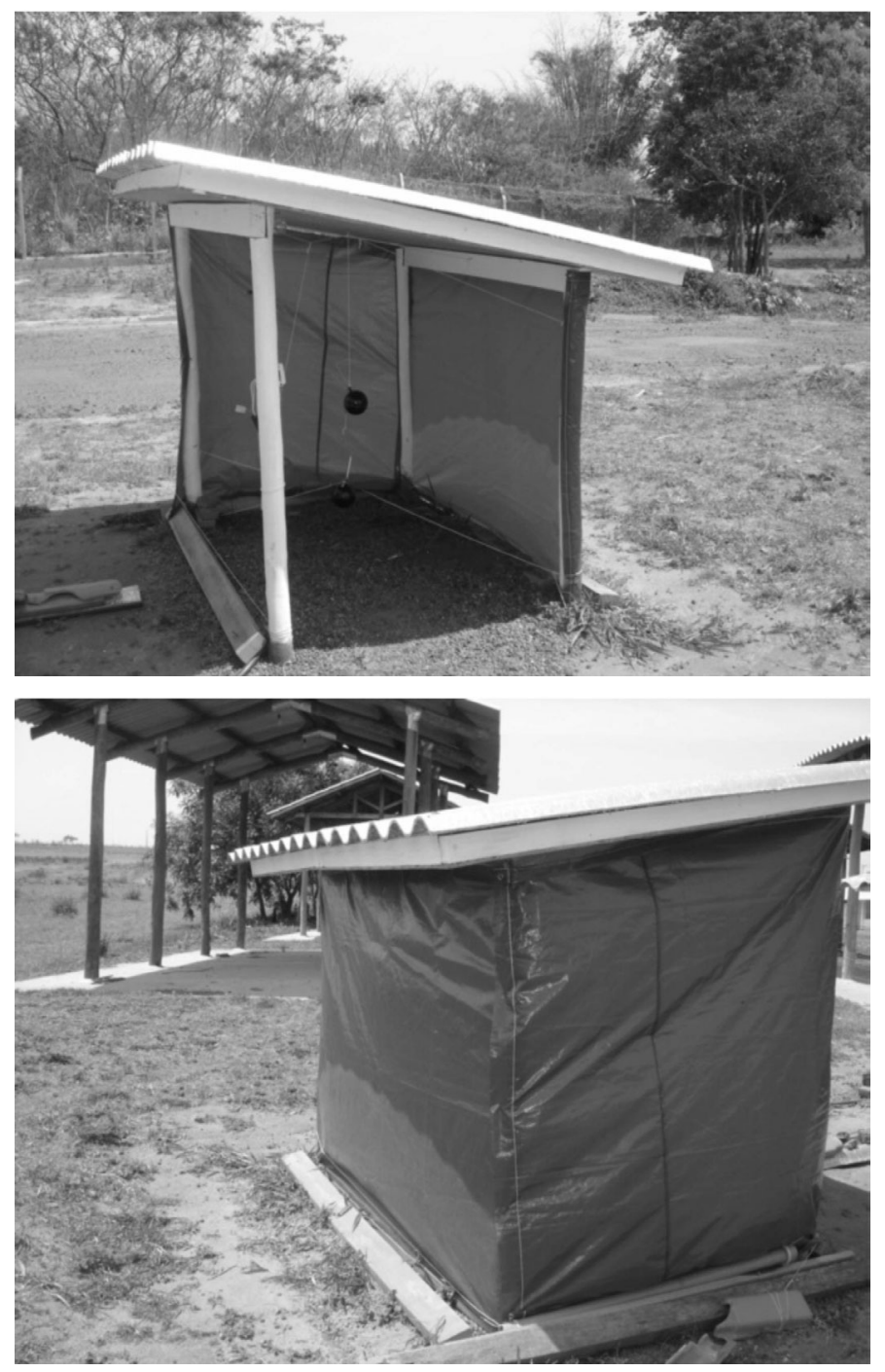

Figure 1. Experimental prototypes in reduced and distorted scale.

The prototypes' roofs were built with a single água, although this is not the most common design for broiler 


\section{Cravo JCM, Fiorelli J, Lahr FAR, Fonseca R da, Cruz VC da}

houses. The roofing material used in both models was recycled tile made of long-life packages, previously evaluated by Fiorelli et al. (2009). The HWC model had a ceiling made of OSB (Oriented Strand Board - 10mm),

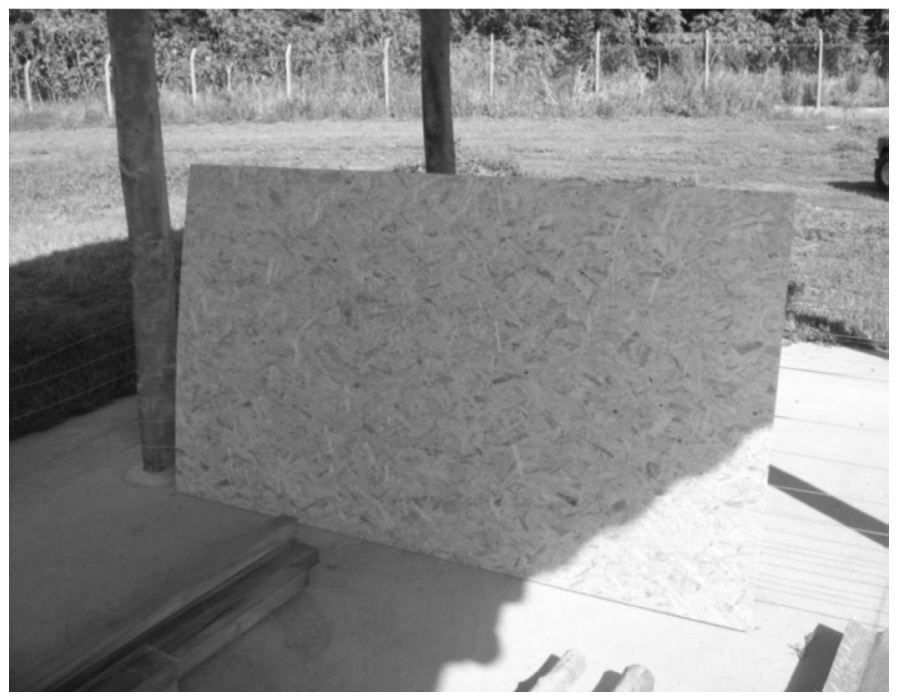

OSB board (10mm)

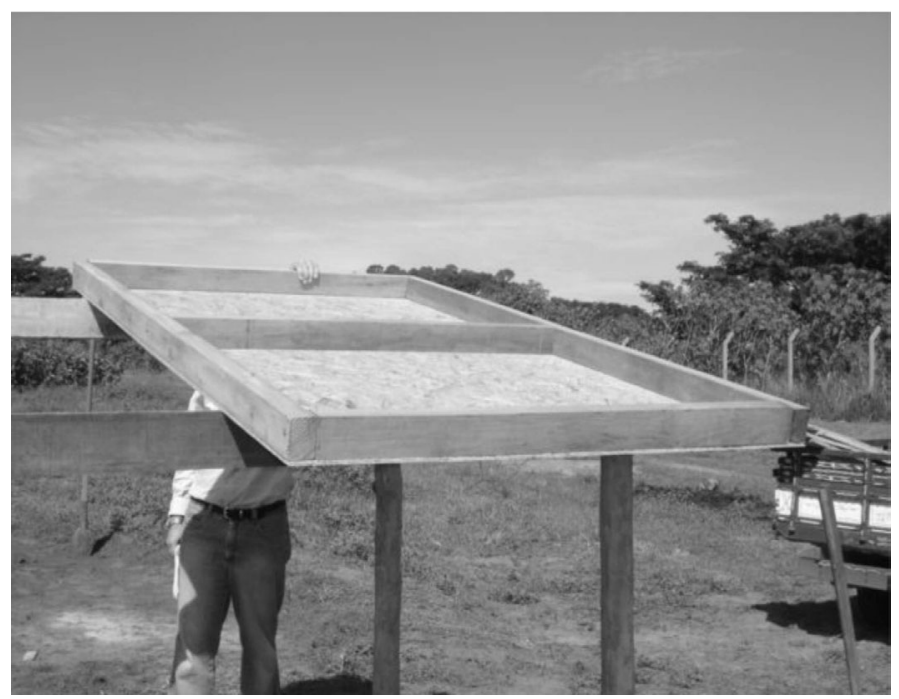

Placement of Module 1
Evaluation of Recycled Tiles and OSB Ceiling Materials in Closed Broiler House Prototypes

which is consists of a reforested wood panel made of three pressed layers of wood strands aligned in scales using a synthetic resin (Figure 2).

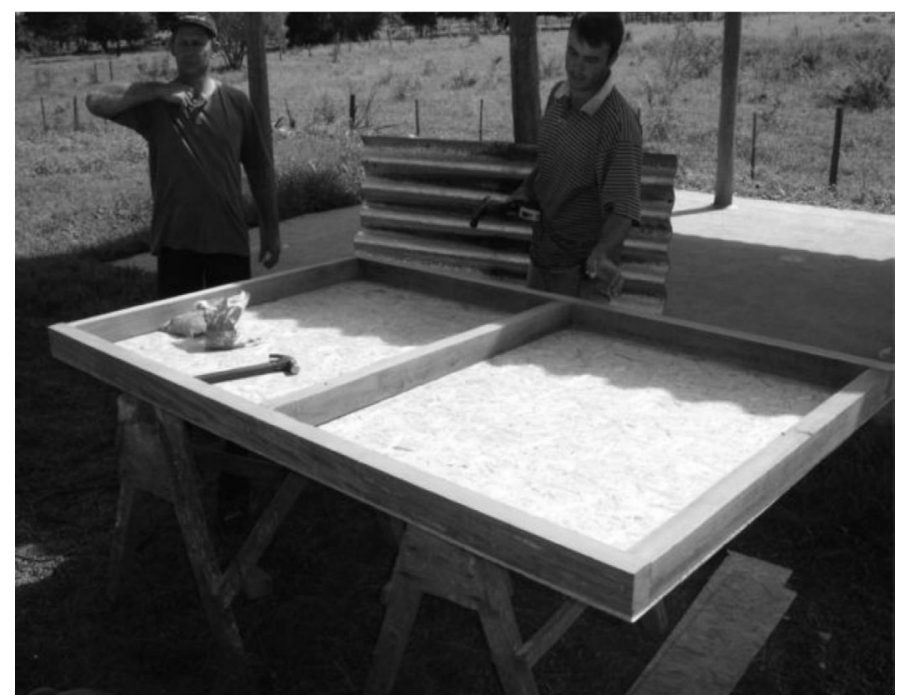

Module 1

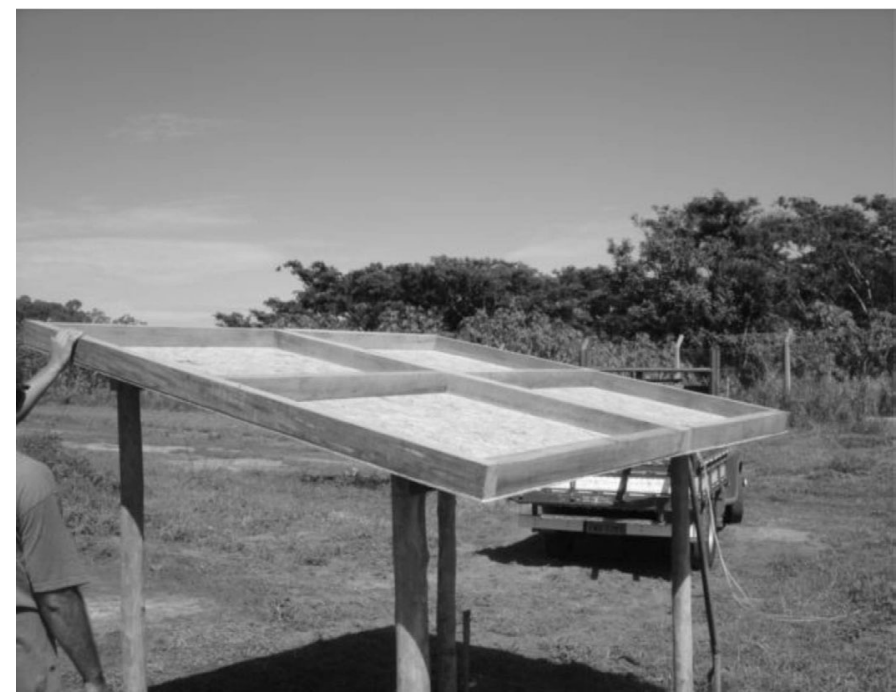

Joining Module 1 and Module 2

Figure 2. Building the OSB modular ceiling.

In order to evaluate the thermal performance of each prototype (HWC and HWOC) and of the external environment (EXT), a dry bulb and wet bulb thermometer, a black globe thermometer, and a digital anemometer were used. The instruments were placed at $0.3 \mathrm{~m}$ distant from the floor, which corresponds to the mass center of broilers inside the house (Santos et al., 2002). Internal temperature (ST) of the roofs was determined using an infrared thermometer
(modelSCAN TEMP $400,-33^{\circ} \mathrm{C} / 550^{\circ} \mathrm{C}$ temperature range) in three different points to provide an uniform sample.

In order to characterize the experimental environment, a weather station (DAVIS, Vantage PRO2) was used. Although summer is considered as the most critical season for broiler production, in the present study, data were collected for 21 days during the spring of 2008, at times when the radiant heat 
Cravo JCM, Fiorelli J, Lahr FAR, Fonseca R da, Cruz VC da
Evaluation of Recycled Tiles and OSB Ceiling Materials in Closed Broiler House Prototypes heat on the prototypes is highest: at 11:00 am, 01:00 pm, and 03:00 pm.. Based on the collected environmental data, WBGT and RHL values were calculated, according to the recommendations of the equation proposed by Buffington et al. (1977) and Esmay (1969), respectively.

Thermal comfort indexes (WBGT and RHL) and the variable ST were analyzed in equation 1 and the regression by equation 2 .

\section{Equation 1}

$$
Y_{i j k}=\mu+a_{i}+h_{j}+(a h)_{i j}+e_{i j k}
$$

$Y_{i j k}=\quad$ th observation of the variable RHL, WBGT, or ST at the jth hour and ith thermal condition

$\mu=$ general mean

$a_{\mathrm{i}}=\quad$ ith level of thermal condition, $\mathrm{i}=\mathrm{HWC}$, HWOC, or EXT

$h_{j}=\quad$ jth level of time, $j=11,01$, or 03

$(a h)_{i j}=$ effect of the interaction between the ith thermal condition level and the jth time level

$\mathrm{e}_{\mathrm{ijk}}=$ residual effect

\section{Equation 2}

$$
Y_{i j}=a+b h_{i}+e_{i j}
$$

$Y_{i j}=\quad$ jth observation of the variable RHL, WBGT, or ST at the ith time level

$\mathrm{a}=$ constant of regression

$\mathrm{b}=$ coefficient of regression

$\mathrm{e}_{\mathrm{ij}}=$ residual effect

After data normality was tested, a parametric test for the comparison of the means (Tukey's) was chosen to analyzed the qualitative data, and quantitative data were analyzed by regression analysis, both at $p<0.05$. The obtained results were evaluated and interpreted by the "R" system for statistical analyses.

\section{RESULTS AND DISCUSSION}

There was no effect of the interaction between thermal condition and time for the studied variables. Table 1 summarizes Tukey's test results for the variables ST, WBGT, and RHL obtained during the 21 days of data collection during the spring. ST mean values obtained in the prototypes were significantly different $(p<0.05)$ : mean ST of the OSB ceiling+recycled tile (HWC) model was significantly lower than that of the model only with recycled tiles (HWOC). This may be explained by the fact that the ceiling of the HWC has lower heat flow due to the air cushion that was formed between the tiles and the ceiling (OSB board). The model with recycled tiles+OSB ceiling reduced ST in $15 \%$ as compared to the model only with tiles. Similar results were obtained by Tinôco (2001), who observed that the ceiling, as it is a second physical barrier, allows the formation of a mobile air layer between the ceiling and the roof, thereby contributing to the reduction of heat transference from the roof to the inside of the building.

WBGT in the external environment (EXT) was significantly higher than in the internal environment of the prototypes (HWC and HWOC) at the birds' mass center because the black globe was directly exposed to radiation, i.e., a higher amount of electromagnetic waves reached the black globe, which propably increased its temperature as compared to the black globes placed inside the experimental prototypes (HWC and HWOC). However, no WBGT differences were detected between the prototype with OSB ceiling+ recycled tiles (HWC) to the prototype without a ceiling (HWOC) (Table 1). Despite the lack of significant differences $(p<0.05)$ in WBGT between the internal environments of the experimental prototypes (HWC and HWOC), the model with ceiling (HWC) presented higher mean WBGT value. It is hypothesized that the shade made by the OSB ceiling+recycled tile prototype (HWC) on the north side of the HWOC may have allowed lower indirect solar radiation on the internal environment of that model.

It was observed that the shading provided by the roofs (HWC e HWOC) reduced WBGT values in $6 \%$ as compared to the external environment. The internal environment of the OSB ceiling+recycled tile prototype (HWC) and of the recycled tile prototype (HWOC) presented similar behavior, and the mean experimental value of the HWC was higher. These results are opposed to the findings of Moraes et al. (1999), who observed lower WBGT when roofing was associated with a polyethylene ceiling.

According to Furtado et al. (2003), WBGT values between 65 and 77 do not influence broiler performance, and can be considered to be in the comfort range. In the present study, WBGT values in all studies environments were higher than the upper temperature of broilers' comfort zone, and therefore, may not provide a good environment for these birds. 


\section{Cravo JCM, Fiorelli J, Lahr FAR, Fonseca R da, Cruz VC da}

RHL values were significantly different $(p<0.05)$ between the external environment (EXT) and the internal environment of the prototypes (HWC and HWOC) at the birds' mass height. This was probably due to the fact that the black globe was directly exposed to solar radiation in the external environment. There as no significant differences $(p<0.05)$ in RHL between the studied prototypes (HWC and HWOC), with the model with OSB ceiling+recycled tiles presenting higher mean experimental value (Table 1). Again, this may be explained by the shading of its north side by the HWC prototype.

The shading generated by the OSB ceiling+recycled tile prototype (HWC) and by the recycled tile roof (HWOC) reduced radiant heat load in approximately $36 \%$, possibly because the plastic curtain provided a physical barrier to the surrounding solar radiation. The internal environment of the prototypes (HWC e HWOC) presented similar behavior, showing that the physical barrier (plastic curtain) hindered the heat loss in the prototype with the ceiling.

\begin{tabular}{|c|c|c|c|c|}
\hline \multicolumn{5}{|c|}{ Internal surface temperature (ST) } \\
\hline HWC & 32.37 & 34.76 & 36.5 & $34.54 \mathrm{~A}$ \\
\hline HWOC & 37.31 & 40.66 & 41.58 & 39.85B \\
\hline \multicolumn{5}{|c|}{ Globe temperature and humidity index (WBGT) } \\
\hline HWC & 83.04 & 84.00 & 86.44 & $84.49 \mathrm{~A}$ \\
\hline HWOC & 82.74 & 84.10 & 85.95 & $84.26 \mathrm{~A}$ \\
\hline EXT & 87.58 & 90.07 & 91.35 & $89.67 \mathrm{~B}$ \\
\hline \multicolumn{5}{|c|}{ radiant heat load $(\mathrm{RHL})-\mathrm{W} / \mathrm{m}^{2}$} \\
\hline HWC & 513.01 & 520.73 & 539.07 & 524.27A \\
\hline HWOC & 510.85 & 521.45 & 535.67 & $522.66 \mathrm{~A}$ \\
\hline EXT & 637.77 & 734.16 & 761.04 & $710.99 B$ \\
\hline
\end{tabular}

Means followed by different capital letters in the same column are different by the test of Tukey $(p<0.05)$.

The graphs shown in Figure $3(A, B$, and $C)$, showing the profile of the studied variables, were based on the regression equations presented in Table 2 .

Table 2. Fitted equations of internal surface temperature (ST), globe temperature and humidity index (WBGT), and radiant heat load (RHL) as a function of time.

\begin{tabular}{lc}
\hline Curve equation & $\mathbf{R}^{2}$ \\
\hline STY $=23.5491^{*}+1.0496^{*} \mathrm{H}$ & 0.96 \\
WBGTY $=74.8963^{*}+0.8646 * \mathrm{H}$ & 0.99 \\
RHLY $=444.590 *+11.214 * \mathrm{H}$ & 0.99 \\
\hline
\end{tabular}

* significant at $p<0.05$.

Figure 3A shows that mean experimental ST values increased as a function of time, and reached its
Evaluation of Recycled Tiles and OSB Ceiling Materials in Closed Broiler House Prototypes

maximum value at 03:00 $\mathrm{pm}$. These results are different from those obtained by Cravo et al. (2008), who observed mean ST values in tiles at 12:00 pm, $01: 00 \mathrm{pm}$, and $02: 00 \mathrm{pm}$ of $38.17^{\circ} \mathrm{C}, 37.42^{\circ} \mathrm{C}, 36.61^{\circ} \mathrm{C}$ in an open house, and $35.05^{\circ} \mathrm{C}, 34.98^{\circ} \mathrm{C}, 34.31^{\circ} \mathrm{C}$ in a closed house, respectively.

In Figure 3B, it is noted that the mean WBGT increased with time up to a peak at 03:00 pm. This behavior demonstrates that the blue plastic curtain is not sufficiently effective to block the heat waves coming from the external environment. This diurnal behavior of the WBGT values were also observed by Rosa (1984), Fonseca (1998), Zanolla et al. (1999), Matos (2001), and Furtado et al. (2003), using different roofing materials than those applied in the present study.
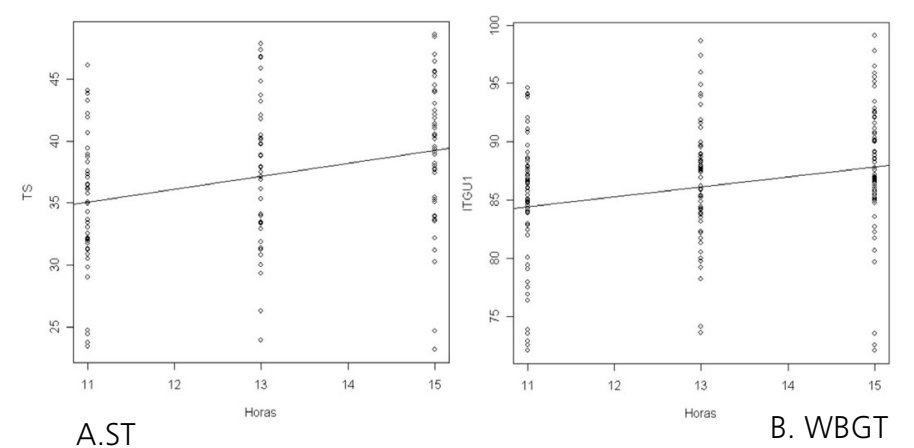

C. RHL

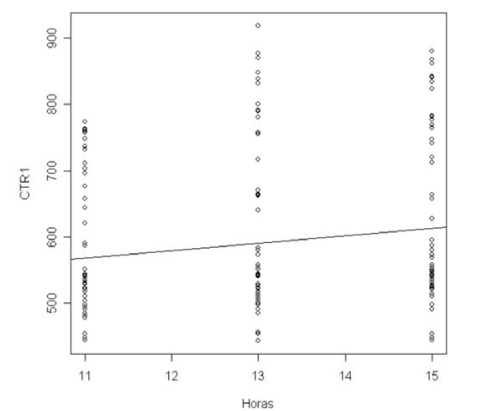

Figure 3. Estimated internal surface temperature (A. ST), globe temperature and humidity index (B. WBGT), and radiant heat load (C. RHL).

In Figure 3C, mean RHL experimental values present similar behavior relative to WBGT and ST, i.e., they all peaked at 03:00 pm. Jacomé et al. (2007) studied the thermal comfort index in developing replacement layer pullets housed under different roofing materials (clay and fibrocement) and obtained higher RHL values at 12:00 pm and 02:00 pm. Abreu et al. (2007) evaluate a polyethylene ceiling in broilers houses with fibrocement 


\section{Cravo JCM, Fiorelli J, Lahr FAR, Fonseca R da, Cruz VC da}

roof, and obtained higher RHL values at 12:00 pm and 03:00 pm, which is consistent with the results of the present study.

Despite being carried out in the spring, which is less critical for broiler production as compared to the summer, the values obtained for the thermal comfort indexes indicate that the roofing system used did not provide proper thermal environment for broiler production.

\section{CONCLUSIONS}

The results obtained in the present study allowed us to conclude that the use of a modular ceiling system in prototypes closed with curtains:

1. Was efficient as it significantly reduce internal roof surface temperature, but did not provide enough thermal comfort for broiler production.

2. Was not significantly efficient to provide adequate WBGT and RHL for broilers.

It is suggested that further research studies on this subject are carried out in real-scale broiler houses with commonly used roof materials and in association with other insulating materials.

\section{REFERENCES}

Abreu PG, Abreu VMN, Coldebella A, Jaenish FRF, Paiva DP. Condições térmicas ambientais e desempenho de aves criadas em aviários com e sem o uso de forro. Arquivo Brasileiro de Medicina Veterinária e Zootecnia 2009; 59(4):1014-1020.

Associação Brasileira dos Produtores e Exportadores de Frangos. [Acesso em: 2008 nov 12]. Disponível em: <http://www.abef. com.br.>

Buffington DE, Collaso-Arocho, Canton G, Pitt D, Thatcher WW, Collier RJ. Black globe humidity comfort index for dairy cows [paper 77-4517]. St. Joseph: Transactions of the ASAE; 1977. $19 p$.

Conceição MN, Alves SP, Ttelatin Júnior A, Silva IJO, Piedade SMS, Savastano Júnior $\mathrm{H}$, Tonoli $\mathrm{G}$. Desempenho de telhas de escória de alto forno e fibras vegetais em protótipos de galpões. Revista Brasileira de Engenharia Agrícola e Ambiental 2008; 12(5):536539.

Costa EC. Arquitetura Ecológica; condicionamento térmico natural. 5 ed. São Paulo: Edgard Blücher; 1982. 264p.

Cravo JCM, Perdigão A, Grecco HAT, Sedano A, Malheiros RN, Fiorelli J. Avaliação do conforto térmico em instalações zootécnicas abertas e fechadas localizadas na região oeste do estado de São Paulo. International Conference Of Agricultural Engineering, XXXVIII Brazilian Congress Of Agricultural Engineering; 2008;
Evaluation of Recycled Tiles and OSB Ceiling Materials in Closed Broiler House Prototypes

Foz do Iguaçu. Parana. Brasil.

Esmay ML. Principles of animal environment. Westport: $A B \mid$ Publ; 1969. $325 p$

Fiorelli J, Morceli JAB, Vaz RI, Dias AA. Avaliação da eficiência térmica da telha reciclada à base de embalagens longa vida. Revista Brasileira de Engenharia Agrícola e Ambiental 2009; 13(2):527531.

Fonseca JM. Efeito da densidade de alojamento sobre o desempenho de frango de corte criados em sistemas de nebulização e ventilação em túnel [dissertação]. Viçosa (MG): Universidade Federal de Viçosa; 1998.

Furtado DA, Azevedo PV, Tinôco IFF. Análise do conforto térmico em galpões avícolas com diferentes sistemas de acondicionamento. Revista Brasileira de Engenharia Agrícola e Ambiental 2003; 7(3):559-564.

Jácome IMTD, Furtado DA, Leal AF, Silva JHV, Moura JFP. Avaliação dos índices de conforto térmico de instalações para poedeiras no nordeste do Brasil. Revista Brasileira de Engenharia Agrícola e Ambiental 2007; 11(5):527-531.

Macari M. Estresse de calor em aves. Anais da XXXVIII Reunião Anual da Sociedade Brasileira de Zootecnia; 2001; Piracicaba, São Paulo. Brasil. p. 686-716.

Matos ML. Conforto térmico ambiente e desempenho de frangos de corte, alojados em dois níveis de alta densidade, em galpões com sistemas de ventilação em túnel e ventilação lateral [dissertação]. Viçosa (MG): Universidade Federal de Viçosa; 2001.

Moraes SRP, Tinôco IFF, Baêta FC, Cecon PR. Conforto térmico em galpões avícolas, sob coberturas de cimento - aminato e suas diferentes associações. Revista Brasileira de Engenharia Agrícola e Ambiental 1999; 3(1):82-89.

Rosa YBCJ. Influência de três materiais de cobertura no índice de conforto térmico, em condições de verão, para Viçosa [dissertação]. Viçosa(MG): Universidade Federal de Viçosa; 1984.

Silva IJO, Sevegnani KB. Ambiência na produção de aves de postura. In: Silva IJO. Ambiência na produção de aves de clima tropical. Piracicaba: FUNEP, 2001. p.150-214, 2001

Santos RC, Tinôco IFF, Paulo MO, Cordeiro MB, Silva JN. Análise de coberturas com telhas de barro e alumínio, utilizadas em instalações animais para duas distintas alturas de pé-direito. Revista Brasileira de Engenharia Agrícola e Ambiental 2002; 6(1):142-146.

Tinôco IFF. Avicultura industrial: novos conceitos de materiais, concepção e técnicas construtivas disponíveis para galpões avícolas brasileiros. Revista Brasileira de Ciência Avícola 2001; 3(1):01-26.

Zanolla N, Tinôco IFF, Baêta FC, Cecon PR, Moraes SRP. Sistemas de ventilação em túnel e lateral na criação de frangos de corte em alta densidade. Revista Brasileira de Engenharia Agrícola Ambiental 1999; 3(3):361-366. 